\title{
Analysis of Strategy for Development of Halal Tourism Potentials in Syariah Hotels in West Java
}

\author{
Usep Deden Suherman \\ Jurusan Akuntansi Syariah Fakultas Syariah dan Hukum \\ UIN Sunan Gunung Djati Bandung \\ Email: usepds@uinsgd.ac.id
}

\begin{abstract}
Halal tourism potential in West Java, especially for sharia hotels is very high so that West Java is a potential area for developing halal tourism. To realize West Java as a halal tourism development area is not easy there are obstacles faced such as the lack of consumer interest in sharia hotels and not many people understand the difference between sharia hotels and conventional hotels. Therefore, this study will examine the development strategy of halal tourism in West Java.

The purpose of this study is l) to identify internal factors (strengths and weaknesses) in the development of sharia tourism in West Java, 2) to identify external factors (opportunities and threats) in the development of sharia tourism in West Java, 3) for knowing the positioning of West Java in the development of sharia tourism and 4) to find out the development strategy of sharia tourism in West Java.

The research method used is qualitative descriptive. The study was conducted on 8 sharia hotels in the West Java region. The data analysis technique used is SWOT analysis using internal factors and external factors of the company.

The SWOT matrix calculation results produce ten alternative strategies, namely encouraging and providing halal certification facilities for sharia hotels, conducting assessment of facilities and infrastructure, halal tourism needs and other supporting elements in West Java, increasing the promotion of sharia tourism through various media and providing tourism information based on information technology that suits the needs of tourists, conducts an inventory of data in collaboration with the city or district government to hotels that implement the concept of sharia in West Java, develop uniqueness as excellence found in sharia hotels in West Java, Cooperate with various parties including the tourism ministry, the community and other stakeholders, equating the perception of the concept of sharia tourism between the government and business actors through halal tourism discussions and seminars, Developing various tourism products Halal with the aim of attracting tourists, conducting training and coaching Islamic tourism HR in accordance with the standards of the MUI, providing a place of worship complete with other worship facilities and infrastructure. The results of this study are expected to be a recommendation to the government of West Java Province and sharia hotels in the development of halal tourism in West Java.
\end{abstract}

Keywords: Halal tourism, Positioning, Sharia.

Abstrak
Potensi pariwisata halal di Jawa Barat, terutama untuk hotel-hotel syariah sangat tinggi
sehingga Jawa Barat merupakan daerah potensial untuk mengembangkan pariwisata
halal. Untuk mewujudkan Jawa Barat sebagai kawasan pengembangan pariwisata halal


tidak mudah, ada kendala yang dihadapi seperti kurangnya minat konsumen di hotel syariah dan tidak banyak orang yang mengerti perbedaan antara hotel syariah dan hotel konvensional. Oleh karena itu, penelitian ini akan meneliti strategi pengembangan pariwisata halal di Jawa Barat. Tujuan penelitian ini adalah 1) untuk mengidentifikasi faktor internal (kekuatan dan kelemahan) dalam pengembangan pariwisata syariah di Jawa Barat, 2) untuk mengidentifikasi faktor eksternal (peluang dan ancaman) dalam pengembangan pariwisata syariah di Jawa Barat, 3) untuk mengetahui posisi Jawa Barat dalam pengembangan pariwisata syariah dan 4) untuk mengetahui strategi pengembangan pariwisata syariah di Jawa Barat.

Metode penelitian yang digunakan adalah deskriptif kualitatif. Penelitian dilakukan pada 8 hotel syariah di wilayah Jawa Barat. Teknik analisis data yang digunakan adalah analisis SWOT menggunakan faktor internal dan faktor eksternal perusahaan.

Hasil perhitungan matriks SWOT menghasilkan sepuluh strategi alternatif, yaitu mendorong dan menyediakan fasilitas sertifikasi halal untuk hotel syariah, melakukan penilaian sarana dan prasarana, kebutuhan wisata halal dan elemen pendukung lainnya di Jawa Barat, meningkatkan promosi pariwisata syariah melalui berbagai media dan menyediakan informasi pariwisata berdasarkan teknologi informasi yang sesuai dengan kebutuhan wisatawan, melakukan inventarisasi data bekerjasama dengan pemerintah kota atau kabupaten ke hotel yang menerapkan konsep syariah di Jawa Barat, mengembangkan keunikan sebagai keunggulan yang ditemukan di hotel syariah di Jawa Barat, Bekerja sama dengan berbagai pihak termasuk kementerian pariwisata, masyarakat dan pemangku kepentingan lainnya, menyamakan persepsi konsep pariwisata syariah antara pemerintah dan pelaku usaha melalui diskusi dan seminar pariwisata halal, Mengembangkan berbagai produk pariwisata Halal dengan tujuan menarik wisatawan, melakukan training dan pembinaan SDM pariwisata Islam sesuai dengan standar MUI, menyediakan tempat ibadah lengkap dengan sarana dan prasarana ibadah lainnya. Hasil penelitian ini diharapkan dapat menjadi rekomendasi kepada pemerintah Provinsi Jawa Barat dan hotel-hotel syariah dalam pengembangan pariwisata halal di Jawa Barat.

\section{Kata Kunci: Pariwisata halal, Positioning, Syariah}

\section{Introduction}

Tourism is an activity that has strategic benefits to support the national economy in this era of globalization. This sector is proclaimed as a sector that is able to absorb labor and also sectors that are able to provide encouragement to develop investment. In the framework of developing this tourism, the state seeks to make plans and policies related to tourism. The policy in developing the tourism sector is done by digging, inventorying and developing tourist objects as the main attraction of tourists. At the present time, tourism is used as a necessity for most people as a form of selfrecognition in order to gain experience, knowledge and keep all fatigue in carrying out daily routine. Likewise, Muslims in Arabia and the Middle East also feel the same way, the amount of publicity and tourism advertising activities through online media is a factor attracting Muslim tourists to travel.

According to Crecentrating, Halal Friendly Travel and Tourism Consultants, 
revealed that the potential for the market for the development of Sharia tourism when viewed from the Muslim population in the world is 1.8 billion or around $28 \%$ of the total world population of 6.4 billion spread in 148 countries. Of the total number of Muslims in the world, $62 \%$ or 972 million are from Asia Pacific. On that basis, the development of halal tourism is a trend of current tourism.

Indonesia is a country that has the largest Muslim community in the world, not yet a pioneer for the development of halal tourism business. With a total workforce of 10,284 million in the tourism sector, the halal tourism business only earns foreign exchange totaling 11.9 billion US dollars. According to data, Sofyan Hospitality Analysis from the World Travel Tourism Council (WTTC), the number was below Singapore's country of US \$ 16 billion and Malaysia amounting to US \$ 15 billion. Even the country of Thailand was able to profit from Islamic tourism totaling 47.4 billion US dollars. Riyanto Sofyan as Chair of the Halal Tourism Acceleration Team of the Ministry of Tourism and the creative economy revealed that the government prepared several strategies to increase Muslim foreign tourists' acceptance so that foreign tourists target 5 million and 240 million local tourists by 2019. To achieve this, several strategies are used. First, promotion and marketing, including building brands, communication strategies and sales. Second, the development of destinations that consist of attractions, construction of facilities, and access to supporting locations. Third, institutional, business, industry and workshop training. This is done so that they understand how to serve tourists more professionally.

At present, the government has determined five areas that are halal tourism development destinations, namely Aceh, West Sumatra and Lombok, DKI Jakarta and West Java. West Java is an area planned to become a sharia tourism destination in Indonesia. This is because West Java has become a center for the Muslim clothing industry and various halal culinary. Apart from that, West Java is a developed province and is the main partner of the country's capital as well as the province that has the best performance of all provinces in Indonesia, prioritizing tourism is an important matter to develop its territory. Through the position which is one of the 6 main businesses in the province of West Java, the tourism sector is strived to provide support to increase the income from the West Java region (Wibowo, 2003: 2).

The very high potential of Islamic tourism in West Java must be balanced by the availability of supporting facilities and infrastructure such as hotels. This statement is similar to that revealed by Saefudin (2015) which states that the high potential of Islamic tourism must be balanced with the availability of supporting facilities, in this case the facilities are Sharia Hotels. Hotels that have their own sharia concept are still a rare item in Indonesia especially in West Java, whereas for the needs of Muslims, the sharia hotel is very necessary. In addition to answering the needs of the Muslim community who visit West Java, this design will certainly help the success of the government program to make Indonesia the center of world sharia tourism (Puskompublik, 2013).

There are several previous studies that support research that will be conducted now, such as research from Puangniyom (2017) which states that to modify the foundations of Thai tourism development, it is important to emphasize the unity and responsibility that must be owned by all sectors. Then Jaelani (2016) provides an overview of the results of his research, namely the development of Islamic tourism requires creative and innovative management functions based on strategic planning, consistent 
implementation and evaluation measured by the value of sharia. Meanwhile, the results of other studies that support the current research are Batour (2015) which states that the opportunities and challenges of halal tourism are increasingly developing in the future. Therefore, this study will examine the analysis of the development of halal tourism potential in sharia hotels in West Java.

\section{Literature Review}

\subsection{Halal Tourism}

Sharia tourism can be called Islamic tourism, sharia tourism, shariah travel, halal tourism, halal tourism destinations, friends that are friendly to friends, halal lifestyle, and so on. Viewed from the industrial aspect, shariah travel is a service that functions to complement and not discard the identity of conventional tourism (Jaelani, 2017: 28). Sharia tourism is an activity that is supported by facilities and infrastructure as well as services carried out by the community, businessmen, government, and local government in accordance with the provisions of Islam (Kemenpar, 2012).

Farahani and Anderson (2009) assert that Islamic tourism can be defined as the travel activities of Muslims when moving from one region to another or when there is one outside their area of residence for a period of less than 1 year and to participate in activities with Islamic encouragement. . Meanwhile, according to Sofyan (2012: 33), suggests that Islamic tourism is tourism based on the provisions of Islamic sharia.

Munir Caudry said that Islamic tourism is a new framework in tourism which is not a religious tourism, for example umroh and hajj. Sharia tourism is tourism that provides holiday services that adjust holiday styles that are tailored to the needs and desires of the Muslims. Therefore, the concept is like a hotel that brings the basis of sharia does not provide services for drinking alcoholic beverages and has a swimming pool and spa that separates men and women (Wuryasti, 2013). Islamic tourism has been agreed to be a strong commercial force (Euromonitor, 2015), especially in the Middle East, with very good prospects (Mintel, 2005). Furthermore, according to Puangniyom (2017: 196) suggests that halal tourism is an activity rooted in Islamic principles. According to Puangniyom (2017) halal tourism is carried out by preparing tourism programs and places designed according to the needs of foreign tourists.

Sharia tourism is a journey while still paying attention to character, worship, and aqeedah in order to gain happiness in the world and hereafter. In this sharia tourism, there is a difference between Islamic tourism and conventional tourism and religious tourism. Halal tourism is more diverse tourism than conventional and religious tourism because halal tourism focuses on halal products and is compatible with Islamic sharia. Halal tourism does not focus on tourism which means travel, but more. There are four main parts in halal tourism which are agreed by Kemenparekraf and MUI (Sucipto and Andayani, 2014: 12) are culinary, Muslim fashion, cosmetics-spa, and hospitality. The indicators of religious tourism in Islam can be summarized as follows: (Jaelani, 2017: 28-29)

a. The cultural framework is linked to Islamic tourism (Islamic cultural sites) (Al-Hamarneh, 2011)

b. Tourism is the same as Muslims (obedient to Islamic values), although it can be developed including nonMuslims (Shakiry, 2008),

c. Religion Travel (pilgrimage and visiting sacred areas in the Islamic world) (Hassan, 2007).

d. Islamic Tourism: A tourist with a new moral scope based on Islamic values, 
ethical scope and standardization (Hassan, 2004).

e. Islamic tourism is a journey that intends to motivate "safety" or activities that originate from the urge of Islam (Din, 1989).

\subsection{Sharia Tourism Characteristics}

Chookaew (2015), stated that there are eight factors of Islamic tourism assessment standards from the aspects of administration and management, namely as follows:

a. Services to tourists must be in accordance with the rules of the Muslims as a whole;

b. Counselors and staff need to have discipline and respect for Islamic principles;

c. Manage activities so as not to intersect with Islamic rules;

d. Infrastructure must be compatible with Islamic principles;

e. Restaurants must have international halal service standards;

f. Service traffic must have a security protection system;

g. There are areas provided for Muslim tourists carrying out religious activities

h. Visiting areas that are not in contact with Islamic principles.

From the characteristics of Islamic tourism proposed by Chookaew (2015), there are four aspects that need to be known in order to support Islamic tourism.

a. Location

The chosen tourism area is what is recommended according to Islamic principles and can develop the spiritual value of tourists.

b. b.Transportation

Implementing a system, for example separating seats between men and women who are not muhrim so that it is in accordance with Islamic law and the maintenance of tourist comfort.

c. Consumption
Islam is very concerned with the aspect of halal consumption, which is stated in Q.S Al-Maidah verse 3. The halal aspect here is good from its nature, how to obtain it or its processing. In addition, research illustrates the encouragement of tourists in terms of food has a major role in determining tourist destinations (Moira, 2012).

d. Hotel

All work processes and facilities are presented in accordance with Islamic principles (Samori and Fadilah, 2013). According to Rosenberg (in Sahida, 2009), the service is not only in food and drinks, but also in the facilities provided for example spa, gym, swimming pool, living room and functional for men and women who must be separated.

\section{Research methods}

This research method used is through qualitative and quantitative descriptive approaches. Descriptive research is intended to explain various social phenomena by using concepts that have been refined (Moleong, 2006). The sample used in the study is the Manager of Lingga Hotel, Narapati Indah Syariah Boutique Hotel \& Convention, Ruby Sharia Hotels, Daarul Jannah Cottage, Orange Home's Sharia, Cinnamon Boutique Sharia Hotels, Airy Eco Sharia and Tibrae Sharia Homestay.

The data processing technique used is SWOT analysis using internal factors and external factors and also uses quantitative strategic planning analysis (Quantitative Strategic Planning Matrix) is the method used based on the objectives that describe the strategists to objectively assess the strategy emphasized on the critical factors of inside and outside.

\section{Research Results and Discussion \\ 4.1. EFE Matrix Analysis (External Factor Evaluation)}


In the process of determining the external environment, information about factors related to opportunities and threats experienced by sharia hotel managers is obtained. Questionnaires are given to the Sharia Hotel management section. The stages in preparing the EFE matrix are to calculate the weight and rating based on the results of the question and answer on the respondent. Then averaged. Next, you can find out the score, which is based on the multiplication between the average weight and rating. The table below illustrates the results obtained from the calculation of averages and scores.

Tabel 1 Matriks EFE(Eksternal Factor Evaluation)

\begin{tabular}{|c|c|c|c|c|}
\hline \multicolumn{2}{|r|}{ Faktor-Faktor Eksternal } & \multicolumn{2}{|c|}{ Average } & \multirow[t]{2}{*}{ Score } \\
\hline No. & Opportunity & Weight & Rating & \\
\hline 1 & $\begin{array}{l}\text { Indonesia is the country with the most } \\
\text { Muslim population in the world }\end{array}$ & 0,116 & 3,38 & 0,393 \\
\hline 2 & $\begin{array}{l}\text { Increased religious awareness for the } \\
\text { Muslims so that it becomes an increasingly } \\
\text { large and real potential }\end{array}$ & 0,097 & 3 & 0,290 \\
\hline 3 & $\begin{array}{l}\text { The growth in spending on the Muslim } \\
\text { tourist segment is the fastest in the world }\end{array}$ & 0,095 & 2,88 & 0,273 \\
\hline 4 & $\begin{array}{l}\text { The source of income obtained by the state } \\
\text { from halal tourism is very large }\end{array}$ & 0,092 & 3,13 & 0,287 \\
\hline 5. & $\begin{array}{l}\text { The development of halal tourism and } \\
\text { awareness of halal products continues to } \\
\text { increase, characterized by the many } \\
\text { requests for halal certification }\end{array}$ & 0,096 & 2,75 & 0,263 \\
\hline \multirow[t]{2}{*}{6} & $\begin{array}{l}\text { The halal tourism development framework } \\
\text { is supported by the Ministry of Tourism }\end{array}$ & 0,094 & 3 & 0,283 \\
\hline & Threats & & & \\
\hline 1 & $\begin{array}{l}\text { The concept of halal tourism which is not } \\
\text { yet clear can be developed in West Java in } \\
\text { particular }\end{array}$ & 0,080 & 3,38 & 0,270 \\
\hline 2 & $\begin{array}{l}\text { The absence of rules in the form of laws } \\
\text { relating to halal tourism. }\end{array}$ & 0,078 & 3,63 & 0,283 \\
\hline 3 & $\begin{array}{l}\text { The development of halal tourism in } \\
\text { Indonesia is still slow compared to the } \\
\text { development of halal tourism in } \\
\text { neighboring countries. }\end{array}$ & 0,082 & 3,63 & 0,296 \\
\hline 4 & $\begin{array}{l}\text { Halal tourism promotion activities have } \\
\text { not been as extensive as public / } \\
\text { conventional tourism. }\end{array}$ & 0,084 & 3,88 & 0,325 \\
\hline & Total & & & 2,96 \\
\hline
\end{tabular}

In the calculation above, the biggest opportunity is obtained, that is Indonesia is the country with the most Muslim population in the world with the resulting weight of 0.393 . With this potential, halal tourism development can certainly be well developed with the assumption of coordination and cooperation between the government as the regulatory holder and halal tourism 
actors. Then the second opportunity that resulted from the calculation of the EFE Matrix was where increased religious awareness for the Muslims became a potential that became increasingly large and real with the resulting score of 0.290. With this potential, it is increasingly becoming a great power and opportunity to develop halal tourism, especially sharia hotels in West Java. Meanwhile, the third opportunity resulting from the calculation of the EFE Matrix is that the source of income obtained by the state from halal tourism is very large with a score of 0.287 . The development of halal tourism if managed properly will be a source of foreign exchange for the government. Therefore, the development of halal tourism will provide considerable benefits for both the government and halal tourism business developers themselves.

The fourth opportunity is the halal tourism development framework supported by the Ministry of Tourism with the resulting weight of 0.283 . The government through the Ministry of Tourism strongly supports the development of halal tourism. On this basis halal tourism actors can develop the potential to develop halal tourism. Then the fifth opportunity generated from the EFE Matrix is that the growth of the Muslim tourist segment expenditure is the fastest in the world with the resulting weight of 0.273 . That reason is what drives the development of halal tourism in West Java. Halal tourism is not limited to halal products, but Islamic attitudes and behavior are shown by halal tourism actors. Furthermore, the last opportunity resulted from the calculation of the EFE Matrix, is the development of halal tourism and awareness of halal products continues to increase, characterized by the many requests for halal certification with the resulting weight of 0.263 . At the present time public awareness of the importance of halal products continues to increase so that it becomes a great opportunity to develop the potential of halal tourism specifically in West Java and generally in Indonesia.

The first threat generated in the EFE Matrix is that halal tourism promotion activities have not been as extensive as general / conventional tourism with the resulting weight of 0.325 . Indeed, this challenge needs to be anticipated by the actors who will develop halal tourism so that a large-scale promotion is needed to develop halal tourism. Most people in West Java do not understand well how the concept of halal tourism. Therefore, it is necessary to conduct a large-scale socialization and promotion of halal tourism.

The second threat obtained from the EFE Matrix is the development of halal tourism in Indonesia is still slow compared to the development of halal tourism in neighboring countries with the resulting weight of 0.296 . This is very clear due to the many factors that influence the development of halal tourism in West Java such as regulations, facilities and infrastructure and so forth so that when compared with neighboring countries it can be said to be still slow.

The third threat generated in the EFE Matrix is the absence of rules in the form of laws relating to halal tourism. With the resulting weights of 2.146. Regulation is a key element that will strengthen the development of halal tourism, especially in Indonesia so that this regulation becomes very important as a form of government policy in supporting halal tourism. Then the fourth threat generated in the EFE Matrix is a concept of halal tourism that is not yet clear that can be developed in West Java, especially with the weight obtained at 0.270. The concept of halal tourism is still unclear, making it difficult for halal tourism actors to develop the halal business.

The number of scores obtained in the calculation of EFE Matrix is 2.96, 
meaning that the responses submitted by sharia hotel managers on external factors are classified both in implementing the strategy to take the existing opportunities and also eliminate threats.

\subsection{Internal Factor Evaluation (IFE) Matrix Analysis}

IFE Matrix Analysis is used to describe the main strengths and weaknesses of sharia hotels through the provision of questionnaires to respondents. Then the processing and calculation of weight, rating and score are carried out. This is so that you can use the right strategy with existing strengths and weaknesses. For more details, the results of the IFE Matrix in sharia hotels can be described as follows.

Table 1 IFE Matrix (Internal Factor Evaluation)

\begin{tabular}{|c|c|c|c|c|}
\hline \multicolumn{2}{|r|}{ Internal Factors } & \multicolumn{2}{|c|}{ Average } & \multirow[t]{2}{*}{ Score } \\
\hline No. & Strength & Weight & Rating & \\
\hline 1 & $\begin{array}{l}\text { Sharia hotels in West Java have tourist } \\
\text { attractions }\end{array}$ & 0,125 & 2,75 & 0,344 \\
\hline 2 & $\begin{array}{l}\text { Sharia hotels in West Java have the } \\
\text { opportunity to become halal tourist } \\
\text { destinations because of their ease of } \\
\text { accessibility }\end{array}$ & 0,139 & 3,00 & 0,417 \\
\hline 3 & $\begin{array}{l}\text { Sharia Hotels in West Java have tourism } \\
\text { facilities and infrastructure such as } \\
\text { Tourism Information centers, halal } \\
\text { certified restaurants, Muslimah Spa and } \\
\text { mosques }\end{array}$ & 0,118 & 2,50 & 0,296 \\
\hline 4 & $\begin{array}{l}\text { Availability of sharia institutions or } \\
\text { organizations and Muslim communities in } \\
\text { the West Java region that support halal } \\
\text { tourism }\end{array}$ & 0,120 & 2,50 & 0,301 \\
\hline 5. & $\begin{array}{l}\text { Habits of Muslim communities in West } \\
\text { Java who often carry out religious } \\
\text { activities. }\end{array}$ & 0,095 & 2,13 & 0,201 \\
\hline 6 & $\begin{array}{l}\text { West Java Province government policy } \\
\text { that supports the development of halal } \\
\text { tourism }\end{array}$ & 0,115 & 2,38 & 0,272 \\
\hline & Weakness & & & \\
\hline 1 & $\begin{array}{l}\text { Some sharia hotel managers in West Java } \\
\text { have not installed a halal label that is } \\
\text { certified from the MUI }\end{array}$ & 0,093 & 3,25 & 0,302 \\
\hline 2 & $\begin{array}{l}\text { HR who are not ready to promote halal } \\
\text { tourism such as from the aspect of service }\end{array}$ & 0,105 & 3,38 & 0,353 \\
\hline 3 & $\begin{array}{l}\text { The government and business people do } \\
\text { not understand the concept of sharia } \\
\text { tourism }\end{array}$ & 0,102 & 3,13 & 0,317 \\
\hline 4 & $\begin{array}{l}\text { The West Java Provincial Government } \\
\text { does not have accurate data on Sharia } \\
\text { Hotels spread in West Java }\end{array}$ & 0,088 & 2,88 & 0,252 \\
\hline & Total & & & 3,05 \\
\hline
\end{tabular}


From the results of the IFE Matrix calculation, the results show that the main strength is that Sharia Hotels in West Java have the opportunity to become halal tourist destinations because of their ease of accessibility with the resulting weight of 0.417 . West Java Province has the opportunity to become a halal tourism area especially from accommodation. This is because the facilities and infrastructure are sufficiently supportive to develop halal tourism in West Java in particular.

The second strength generated from the IFE Matrix is that Sharia Hotels in West Java have a tourist attraction with a total score of 0.344 . The tourist attraction is the excellence of West Java itself so that it is feasible to be developed again into a halal tourism area and the attraction is also the uniqueness of West Java which has become a source of excellence for developing such tourism. Furthermore, the third strength generated from the IFE Matrix is the availability of sharia institutions and organizations and the Muslim community in the West Java region that supports halal tourism with a total score of 0.301 . Sharia institutions are a source of support for the implementation of halal tourism programs in West Java so that the strength factor becomes very important to be considered by halal tourism business actors in West Java. Furthermore, the fourth strength is that Sharia Hotels in West Java have tourism facilities and infrastructure such as Tourism Information centers, halal certified restaurants, Muslimah and mosque Spa with the resulting score weight of 0.296. The availability of facilities and infrastructure is very important as a major supporting factor in developing halal tourism in West Java. Therefore, the development of halal tourism in West Java can be carried out well with the support.
The fifth strength generated from the IFE Matrix is the government policy of West Java Province which supports the development of halal tourism with the resulting weight of 0.272 . The government policy has become a major force for halal industry players to develop and promote sharia hotels as halal tourism programs recommended by the West Java provincial government. The last strength generated from the IFE Matrix is the Habit of Muslim Communities in West Java who often perform religious activities with a score of 0.201 . These activities are routine activities that are often held by Muslim communities in West Java so that activities can be supported by facilities and infrastructure such as providing sharia hotels as a place for religious activities.

Apart from the element of strength there are also elements of weakness. Based on the results of the IFE Matrix, the main drawback is the human resources who are not ready to promote halal tourism as from the aspect of service with a total score of 0.353. Human Resources are a very decisive factor in the development of halal tourism. The human resources that will play a role in the development of halal tourism must be HR-HR who understand well about Islamic sharia as evidenced by Islamic attitudes and behavior. Thus, it is necessary to prepare HR in accordance with the characteristics of Islamic sharia. The second weakness resulting from the IFE Matrix is that the government and business actors do not understand the concept of Islamic tourism with a total score of 0.317. This is a fundamental weakness that needs to be well anticipated by the government and business actors so that there is a common concept of halal tourism.

Furthermore, the third weakness resulting from the IFE Matrix is that some halal industry players in West Java have 
not included halal labels that are certified from the MUI with the resulting weight of 0.302 . This problem is a problem that needs attention from halal certification providers where the institution can provide guidance to halal tourism business actors how to obtain the halal certificate. This halal certificate is very important to be obtained by businesses based on halal tourism. This is because the certificate is proof that the business has been said to be lawful from anything that is not allowed in Islam.

The last weakness produced by the IFE Matrix is that the West Java Provincial Government does not have accurate data on Sharia Hotels in West Java with the resulting weight of 0.252 . This is a weakness that needs to be addressed by the West Java Provincial Government to collect data on Islamic businesses such as the existence of sharia hotels spread throughout the West Java region so that if the data is known, the West Java Provincial Government can easily promote the sharia hotels. in the area or region of West Java. This will greatly help to develop halal tourism in West Java. The overall weight in the IFE Matrix is 3.05. Thus, Sharia Hotels in West Java are very capable of using the power they have by closing the weaknesses found in sharia hotels.

\subsection{I-E Matrix Analysis (Internal- External)}

Internal and external matrix analysis is an analysis that combines IFE and EFE matrices where in this stage will be obtained what strategies are suitable to be developed by sharia hotels in West Java. To find out where the IE Matrix position is obtained from the results of the total score combined from the IFE and
EFE Matrix so that by combining the factors of strengths and weaknesses and opportunities and threats, the right strategy to be developed by sharia hotels in West Java will be obtained.

The result of the sum of IFE Matrix (3.05) and EFE Matrix (2.96), the sharia hotel is in quadrant III position. In this quadrant is the position of turnd around strategy in developing the potential of sharia tourism in West Java so that the strategy that can be done is to take advantage of huge opportunities by using the WO strategy.

\subsection{SWOT Matrix Analysis}

SWOT Matrix Analysis is an adjustment stage to obtain a very suitable alternative strategy implemented by sharia hotel managers through the results of the calculation of strengths, weaknesses, opportunities and threats that have been determined using the IFE Matrix and EFE Matrix. The strategies obtained are adjustments or a combination of strengths with opportunities (S-O), weaknesses and opportunities (W-O), strengths with threats (S-T), weaknesses and threats $(\mathrm{W}-\mathrm{T})$. On the basis of the main strategies obtained from the calculation results.

The IE (Internal-External) Matrix of sharia hotel managers is in the position of a turnd around strategy where sharia hotels have enormous opportunities in halal tourism development. Thus sharia hotel managers can formulate strategies based on the position of sharia hotels including market penetration and service improvement. SWOT Matrix Diagram of sharia hotel managers can be seen in the following table. 
Table 3 SWOT Matrix Analysis

\begin{tabular}{|c|c|c|}
\hline Internal & Strenght & \\
\hline Eksternal & $\begin{array}{l}\text { 1. Sharia hotels in West } \\
\text { Java have tourist } \\
\text { attractions } \\
\text { 2. Sharia hotels in West } \\
\text { Java have the } \\
\text { opportunity to become } \\
\text { halal tourist } \\
\text { destinations because of } \\
\text { their ease of } \\
\text { accessibility } \\
\text { 3. Sharia Hotels in West } \\
\text { Java have tourism } \\
\text { facilities and } \\
\text { infrastructure such as } \\
\text { Tourism Information } \\
\text { centers, halal certified } \\
\text { restaurants, Muslimah } \\
\text { Spa and mosques } \\
\text { 4. Availability of sharia } \\
\text { institutions } \\
\text { organizations and } \\
\text { Muslim communities in } \\
\text { West Java that support } \\
\text { halal tourism } \\
\text { 5. Habits } \\
\text { communities in West } \\
\text { Java often do religious } \\
\text { activities. } \\
\text { The policy of the } \\
\text { government of West } \\
\text { Java Province that } \\
\text { development of halal } \\
\text { tourism }\end{array}$ & $\begin{array}{l}\text { 1. Some sharia hotel } \\
\text { managers in West Java } \\
\text { have not installed a halal } \\
\text { label that is certified } \\
\text { from the MUI } \\
\text { 2. HR who are not ready to } \\
\text { promote halal tourism } \\
\text { such as from the aspect } \\
\text { of service } \\
\text { 3. The Government and } \\
\text { Sharia Hotel business } \\
\text { actors have not } \\
\text { understood the concept } \\
\text { of sharia tourism } \\
\text { 4. The West Java } \\
\text { Provincial Government } \\
\text { does not yet have } \\
\text { accurate data on Sharia } \\
\text { Hotels in West Java }\end{array}$ \\
\hline Oppurtinity & Strategy S-O & Strategy $\mathrm{W}-\mathrm{O}$ \\
\hline $\begin{array}{l}\text { 1. Indonesia is the } \\
\text { country with the } \\
\text { largest number of } \\
\text { Muslim communities } \\
\text { in the world } \\
\text { 2. Increased religious } \\
\text { awareness for the } \\
\text { Muslims so that it } \\
\text { becomes } \\
\text { increasingly large and } \\
\text { real potential }\end{array}$ & $\begin{array}{l}\text { 1. Providing a place of } \\
\text { worship complete with } \\
\text { other worship facilities } \\
\text { and infrastructure } \\
\text { 2. Develop various halal } \\
\text { tourism products with } \\
\text { the aim of attracting } \\
\text { tourist }\end{array}$ & $\begin{array}{l}\text { 1. Encourage and provide } \\
\text { halal certification } \\
\text { facilities for sharia hotels } \\
\text { 2. Conduct training and } \\
\text { mentoring of Islamic } \\
\text { tourism HR in } \\
\text { accordance with MUI } \\
\text { standards } \\
\text { 3. Equalize the perception } \\
\text { of the concept of sharia } \\
\text { tourism between the }\end{array}$ \\
\hline
\end{tabular}




\begin{tabular}{|c|c|c|}
\hline $\begin{array}{l}\text { 3. The growth in the } \\
\text { expenditure of the } \\
\text { Muslim tourist } \\
\text { segment is the fastest } \\
\text { in the world } \\
\text { 4. The source of income } \\
\text { obtained by the state } \\
\text { from halal tourism is } \\
\text { very large } \\
\text { 5he development of } \\
\text { halal tourism and } \\
\text { awareness of halal } \\
\text { products continues to } \\
\text { increase, } \\
\text { characterized by the } \\
\text { many requests for } \\
\text { halal certification } \\
\text { The halal tourism } \\
\text { development } \\
\text { framework } \\
\text { supported by the } \\
\text { Ministry of Tourism }\end{array}$ & & $\begin{array}{lr}\text { government } & \text { and } \\
\text { business actors } & \text { through } \\
\text { halal } & \text { tourism } \\
\text { discussions } & \text { and } \\
\text { seminars } & \end{array}$ \\
\hline $\begin{array}{l}\text { Threats } \\
\text { 1. The concept of halal } \\
\text { tourism which is not } \\
\text { yet clear can be } \\
\text { developed in West } \\
\text { Java in particular } \\
\text { 2. The absence of rules } \\
\text { in the form of laws } \\
\text { relating to halal } \\
\text { tourism. } \\
\text { 3he development of } \\
\text { halal tourism in } \\
\text { Indonesia is still slow } \\
\text { compared to the } \\
\text { development of halal } \\
\text { tourism in } \\
\text { neighboring countries } \\
\text { 4alal tourism } \\
\text { promotion activities } \\
\text { have not been as } \\
\text { extensive as public / } \\
\text { conventional tourism. }\end{array}$ & $\begin{array}{l}\text { Strategy S-T } \\
\text { 1. Conducting assessment } \\
\text { on facilities and } \\
\text { infrastructure, halal } \\
\text { tourism needs and } \\
\text { other supporting } \\
\text { elements in West Java } \\
\text { 2. Collaborating with } \\
\text { various parties } \\
\text { including the ministry } \\
\text { of tourism, the } \\
\text { community and other } \\
\text { stakeholders }\end{array}$ & $\begin{array}{l}\text { Strategy W-T } \\
\text { 1. Developing uniqueness } \\
\text { as an advantage found in } \\
\text { sharia hotels in West } \\
\text { Java } \\
\text { 2. Increasing the } \\
\text { promotion of sharia } \\
\text { tourism through various } \\
\text { media and providing } \\
\text { tourism information } \\
\text { based on information } \\
\text { technology that suits the } \\
\text { needs of tourists } \\
\text { 3. Carry out data inventory } \\
\text { by collaborating with } \\
\text { the city or district } \\
\text { government on hotels } \\
\text { that apply the concept of } \\
\text { sharia in West Java }\end{array}$ \\
\hline
\end{tabular}

4.5. QSPM (Quantitative Strategic Planning Matrix)

The quantitative strategic planning matrix is the final step in determining which alternative strategies can best be done by sharia hotels. In this QSPM matrix presents an overview of the advantages of star strategies which then 
become an objective basis in order to have several strategies that are chosen. From the results of the calculation, the alternative strategies that can be done to develop sharia hotels are as follows:

a. Providing a place of worship complete with other worship facilities and infrastructure

b. Develop various halal tourism products with the aim of attracting tourists

c. Encourage and provide halal certification facilities for sharia hotels

d. Conduct training and development of Islamic tourism HR in accordance with MUI standards

e. Equalize the perception of the concept of sharia tourism between the government and business actors through discussions and seminars on halal tourism

f. Conduct assessment of facilities and infrastructure, halal tourism needs and other supporting elements in West Java

g. Cooperating with various parties including the ministry of tourism, the community and other stakeholders

h. Developing uniqueness as excellence found in sharia hotels in West Java

i. Increasing the promotion of sharia tourism through various media and providing tourism information based on information technology that suits the needs of tourists

j. Carry out data inventory by collaborating with the city or district government on hotels that apply the concept of sharia in West Java

The results of calculations with QSPM analysis on sharia hotels in West Java can be sorted as follows:

a. Encourage and provide halal certification facilities for sharia hotels (Total value of attraction 20.49)

b. Conduct assessment of facilities and infrastructure, halal tourism needs and other supporting elements in West Java (Total value of attraction of 20.31) c. Increasing the promotion of sharia tourism through various media and providing tourism information based on information technology that suits the needs of tourists (Total value of attraction 20.26)

d. Carry out data inventory by collaborating with the city or district government on hotels that apply the concept of sharia in West Java (Total value of attraction 19.87)

e. Developing uniqueness as excellence found in sharia hotels in West Java (Total value of attraction 18.42)

f. Cooperate with various parties including the ministry of tourism, the community and other stakeholders (Total value of attractiveness 17.97)

g. Equalize the perception regarding the concept of sharia tourism between the government and business actors through halal tourism discussions and seminars (Total value of attractiveness 17.48)

h. Develop various halal tourism products with the aim of attracting tourists (Total value of attractiveness 17.47)

i. Conduct training and development of Islamic tourism HR in accordance with MUI standards (Total value of attraction 16.51)

j. Providing a place of worship complete with other worship facilities and infrastructure (Total value of attraction 16.28)

\section{Conclusion}

Research on the analyst of the development of halal tourism potential in sharia hotels in West Java can be concluded, among others:

1. Internal factors that influence the development of sharia tourism in West Java include strengths and weaknesses. Strengths include sharia hotels in West Java have tourist attractions, sharia hotels in West Java have the potential to become one of the halal tourist destinations because of ease of 
accessibility, sharia hotels in West Java have tourism facilities and infrastructure such as Tourism Information center, halal certified restaurants, spas Muslim women and mosques, the availability of sharia institutions and organizations and Muslim communities in the West Java region that support halal tourism, the custom of Muslim communities in West Java who often carry out religious activities, the policy of the West Java Province government that supports the development of halal tourism. The weakness is that some halal industry players in West Java have not labeled halal certified from the MUI, HR is not ready to develop halal tourism, especially in services such as guides who have not fully implemented Islamic principles in assisting tourists, the government and businesses do not understand the concept Islamic tourism and the West Java Provincial Government do not yet have accurate data on Sharia Hotels in West Java.

2. External factors affecting sharia tourism in West Java include opportunities and threats. Opportunities include Indonesia is a country with the largest number of Muslim citizens in the world, increasing religious awareness for Muslims so that it becomes an increasingly large and real potential, the growth of shopping for Muslim tourists is the fastest in the world. , the development of halal tourism and awareness of halal products continues to increase, characterized by the many requests for halal certification, and the halal tourism development framework supported by the Ministry of Tourism. While the threat is the concept of halal tourism that is not yet clear can be developed in West Java in particular, the absence of rules in the form of laws relating to halal tourism, the development of halal tourism in Indonesia is still slow compared to the development of halal tourism in neighboring countries and halal tourism promotion activities not as extensive as public / conventional tourism.

3. Judging from the positioning, a turnd around strategy can be established in increasing halal tourism opportunities in West Java, standing in quadrant III so using the WO strategy. This position is a position where West Java faces enormous opportunities despite internal weaknesses.

4. Strategies that can be carried out to develop sharia tourism are to encourage and provide halal certification facilities for sharia hotels, conduct assessments of facilities and infrastructure, halal tourism needs and other supporting elements in West Java, improve sharia tourism promotion through various media and provision tourism information based on information technology that suits the needs of tourists, conducts data inventory in collaboration with the city or district government on hotels that implement the concept of sharia in West Java, develops uniqueness as excellence found in sharia hotels in West Java, doing cooperation with various parties including the ministry of tourism, the community and other stakeholders, equating perspectives on the concept of sharia tourism between the government and business actors through discussions and seminars on halal tourism, Developing various tourism products Halal with the aim of attracting tourists, conducting training and coaching Islamic tourism HR in accordance with the standards of the MUI, providing a place of worship complete with other worship facilities and infrastructure. 


\section{BIBLIOGRAPHY}

Andayani, Hery Suciptodan Fitria. 2014. Wisata Syariah (Karakter, Potensi,. Prospek, dan Tantangannya). Jakarta Selatan: Grafindo.

Chookaew, S. 2015. Increasing Halal Tourism Potential at Andaman Gulf in Thailand for Muslim Country. Journal of Economics, Business and Management, 739-741.

Jaelani, Aan. 2017. Halal Tourism Industry in Indonesia: Potential and Prospects. International Review of Management and Marketing, 2017, 7(3), 25-34.

2016. Islamic Tourism Development In Cirebon: The Study Heritage Tourism in Islamic Economic. Journal of Shari'a and Islamic Economic Faculty IAIN Syekh Nurjati Cirebon

Kemenpar. 2012. Kemenparekraf Promosikan Indonesia Sebagai Destinasi Pariwisata Syariah Dunia. http: www.kemenpar.go.id

Mintel. 2005. Religious Tourism. Mintel: London.

Moleong Lexy, J. 2001. Metodologi penelitian kualitatif. Bandung: Remaja Rosdakarya.

Piyachat Puangniyom. 2017. Halal Tourism Strategy to Promote Sustainable Cultural Tourism in Thailand. International Conference on Studies in Arts, Social Sciences and Humanities (SASSH-17) Jan. 26-27, 2017, Cebu (Philippines)

Puskompublik. 2013. Indonesia Miliki Potensi Besar Untuk Kembangkan Wisata Syariah. http://www.parekraf.go.id/asp/detil asp?c=16\&id=2466.

Saefudin, Akhmad. 2015. Wisata Berbasis Syariah. Category: SmCetak, Wacana A+ / A-. http://berita.suaramerdeka.com/smc etak/wisata-berbasis-syariah/

Sofyan, Riyanto. 2012. Prospek Bisnis Pariwisata Syariah. Jakarta:

Republika.

Wibowo, Lili. 2003. Experiential Marketing Pengaruhnya terhadap Branded Customer Experience dan Loyalitas Pelanggan Restoran dan Cafe Serta Dampaknya Pada Citra Bandung Sebagai Destinasi Pariwisata Indonesia. Jurnal manajemen pemasaran UPI

Wuryasti, Fetri. 2013. Wisata Halal, Konsep Baru Kegiatan Wisata di Indonesia. http://travel.detik.com:

Zamani-farahani, H. \& Henderson J. C. 2009. Islamic Tourism and Managing Tourism. International Journal Of Tourism Research. Int. J. Tourism res. 12, 79-89 (2010)

Euromonitor International. 2015. Doing business in the HalalMarket: Products, trends, and growth opportunities. (Retrieved from http://go.euromonitor.com/whitepaperbusiness- halal-marketproducts-trends-growthopportunities.html) 